\title{
Investigating Cognitive Presence in Learning Academic Writing Online
}

Noor Hanim Rahmat, Ira Syaqira Sukimin, Siti Aishah Taib, Norhafizah Amir, Nur Sherina Zainal Abidin

To Link this Article: http://dx.doi.org/10.6007/IJARBSS/v12-i1/12191

DOI:10.6007/IJARBSS/v12-i1/12191

Received: 16 November 2021, Revised: 19 December 2021, Accepted: 08 January 2022

Published Online: 28 January 2022

In-Text Citation: (Rahmat et al., 2022)

To Cite this Article: Rahmat, N. H., Sukimin, I. S., Taib, S. A., Amir, N., \& Abidin, N. S. Z. (2022). Investigating Cognitive Presence in Learning Academic Writing Online. International Journal of Academic Research in Business and Social Sciences, 12(1), 2167-2178.

Copyright: (C) 2022 The Author(s)

Published by Human Resource Management Academic Research Society (www.hrmars.com)

This article is published under the Creative Commons Attribution (CC BY 4.0) license. Anyone may reproduce, distribute, translate and create derivative works of this article (for both commercial and non0-commercial purposes), subject to full attribution to the original publication and authors. The full terms of this license may be seen

at: http://creativecommons.org/licences/by/4.0/legalcode

Vol. 12, No. 1, 2022, Pg. 2167- 2178

Full Terms \& Conditions of access and use can be found at http://hrmars.com/index.php/pages/detail/publication-ethics 


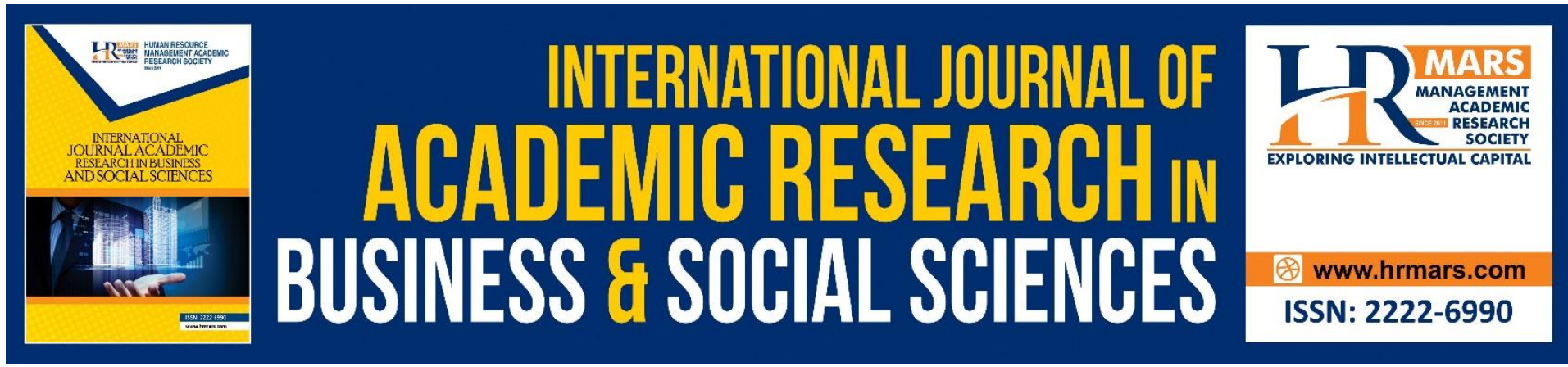

\title{
Investigating Cognitive Presence in Learning Academic Writing Online
}

\author{
Noor Hanim Rahmat ${ }^{1}$, Ira Syaqira Sukimin², Siti Aishah Taib³, \\ Norhafizah Amir ${ }^{4}$, Nur Sherina Zainal Abidin ${ }^{5}$ \\ ${ }_{1,3}$ Akademi Pengajian Bahasa, Universiti Teknologi MARA Cawangan Johor, \\ Kampus Pasir Gudang, ${ }^{2,4,5}$ Akademi Pengajian Bahasa, Universiti teknologi MARA Cawangan \\ Johor, Kampus Segamat \\ Email:noorh763@uitm.edu.my, irasyaqira@uitm.edu.my, aishah711@uitm.edu.my, \\ norhafizah.amir@uitm.edu.my \& nursherina@uitm.edu.my
}

\begin{abstract}
Writing today includes the act of tapping onto the keyboards of the computer to compose text for publication. Publication here can mean the simple act of getting the text ready to be read by the audience. The wave of online learning has added more challenges to learn academic writing. Writing is an activity that requires engagement. When it comes to academic writing, there are internal and external factors that contribute to the challenges. This study is done to investigate how learners perceive learning academic writing online. After undergoing a semester of learning academic writing, online, learners were asked to respond to a survey. It has 4 sections and used a 5 -likert scale. The first section is the demographic profile, the section is on planning, the third is on translating and the last section is on reviewing. Data analysis showed that leaners perceived that planning was not as important as the translating and reviewing stages. Findings has interesting pedagogical implications for the teaching of academic writing online.
\end{abstract}

Keywords: Academic Writing, Online, Planning, Translating, Reviewing

\section{Introduction}

Writing is an activity that requires engagement. According to Haron \& Rahmat (2020), writing is a conversation between the writer and the reader. Information is being transferred from the writer to the reader. Sometimes information gets transferred the way it was meant to, sometimes some details get distorted or sometimes some meaning gets lost along the way. Writing is a long and sometimes, not very pleasant process for writers. For example, the learning and teaching of academic writing may not be a pleasant process for both the learners and the writing teachers. This is because academic writing involves thinking about writing, and making plans (Rahmat, 2020) . Learning academic writing is not an easy task as writing process involves stages like (a) planning, (b) translating and (c) evaluating. When it comes to academic writing, Hidayati (2018) found there are internal and external factors that contribute to the challenges. The internal factors include linguistic competence, native 
language interference, motivation and reading habits of the learners, while the external ones include the class condition, aids available for teaching writing and the availability of time.

The wave of online learning has added more challenges to learn academic writing. Learning online already has many drawbacks. According to Muncundayi (2019), one main problem with online classes is the participation (or lack) of learners in online courses. Past studies have even shown that the three types of engagement (Moore,1989) are often compromised. The three types of engagement are learner-to-content, Learner-to-instructor and Learner-tolearner. In learning writing online, the environment is the online platform. The study by Othman, Rahmat , Aripin \& Sardi (2022) has shown that writing environment plays important role in the academic writing process. So, learning about academic writing is already not an easy task. The online platform seems to add more disadvantages to the learning of academic writing than it already has. How do learners perceive learning academic writing online?

This study is done to investigate how learners perceive learning academic writing online. Specifically, this study is done to answer the following questions;

How do learners select content during online writing?

How do learners connect ideas in online writing? (translate)

How do learners support discourse in online writing? (evaluation)

\section{Literature Review}

Introduction

This section discusses the issues about learning academic writing online, past studies on learning academic writing online, and also past studies. The section ends with the presentation of the conceptual framework of the study.

\section{Learning Academic Writing Online}

Online Learning

The conditions for learning traditional and online may or may not differ much. Moore (1989) said that in order for an online to be successful, there should be engagement like (a) learner-to-content, (b) learner-instructor and also (c) learner to-content. There are basically two types of engagement and they are behavioural and cognitive engagement. Behavioural is when learners actively participate in the learning process. They show up on time, turn in their homework and bring the materials they need for class. Next, cognitive engagement is when students try to learn as much as they can. They participate in activities that help them to maximise their learning.

In addition to that, one of the factors (refer to figure 1 ) that make online learning is the existence of three type of presence during online interactions (Garrison \& Arbaugh, 2007); (a) teaching presence, (b) social presence and (c) cognitive presence. Firstly, teaching presence is seen as the work of teaching that is done before and during the course. This includes all the preparatory work in designing and developing the course and the hands-on teaching of directing and supporting the learners during the course delivery. Next, social presence is the ability to the learners to engage socially and affectively and to get to know one another as three-dimensional people despite not meeting face-to-face. Social presence is the foundation of building trust and presence for the teaching and learning experiences. Finally, cognitive presence is described as the extent to which learners are able to create meaning through the online interactions. This is done by integrating existing learning with new learning requires knowledge, reflection, discussion and confirming of meaning. 


\section{The Community of Inquiry Model}

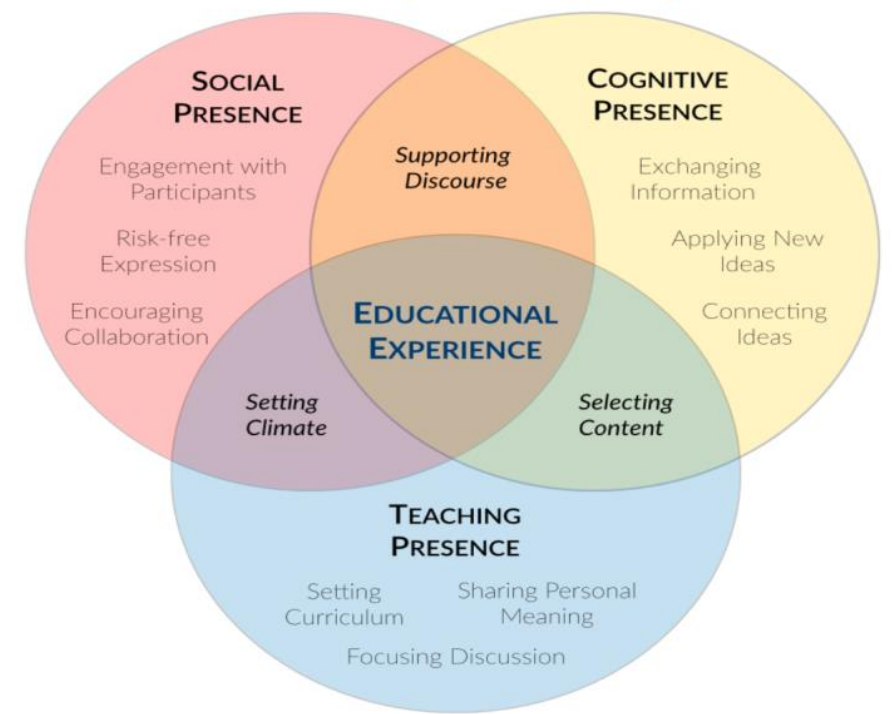

Figure 1-The Community of Inquiry Model (Source : Garrison \& Arbaugh, 2007)

\section{Connectivism}

One popular theory in the digital age is connectivism. Connectivism has been offered as a new learning theory for a digital age, with four key principles for learning: autonomy, connectedness, diversity, and openness (Siemen, 2005). This theory is built upon several principles. The first principle is learning and knowledge rests in diversity of opinions. Next, learning is a process of connecting specialized nodes or information sources. The third principle is learning may reside in non-human appliances-in this case learning resides in devices (like the computer and electronic gadgets). Next, the capacity to know more is more critical than what is currently known that is why some spent hours in connected on the internet on a "snowball wave" of getting from one information to another related information. The fifth principle looks at the nurturing and maintaining connections as a way to facilitate continual learning. Next, the ability to see connections between fields, ideas, and concepts is a core skill. The next principle states that the currency (accurate, up-to-date knowledge) is the intent of all connectivist learning activities. Finally, decision-making is itself a learning process. Choosing what to learn and the meaning of incoming information is seen through the lens of a shifting reality. While there is a right answer now, it may be wrong tomorrow due to alterations in the information climate affecting the decision.

\section{Learning the Writing Process}

The definition of writing has changed over the years to suit the growing needs of writing. Writing was once seen a physical activity that involves using the hand to transcribe word onto a piece of paper. Writing today includes the act of tapping onto the keyboards of the computer to compose text for publication. Publication here can mean the simple act of getting the text ready to be read by the audience. According to Carolan \& Kyppö (2015), writing on a computer with a keyboard has a somewhat different dynamic to writing by hand with a pen or pencil. Excessive use of technology is likely to speed up the entire writing process, which is not necessarily a positive outcome. This is because a lot takes place in the mind of the writer during the writing process. 
Writers go through several stages in the writing process. Figure 2 presents the writing process by Flower and Hayes (1981). Writer's planning begins as the writer uses his/her long term memory to retrieve background knowledge for the writing activity. According to Rahmat, Aripin, Lin, Whanchit, and Khairuddin (2020), writers spent a large section of their writing time on the planning stage. During this stage, he /she uses his/her knowledge of topic, audience and then made stored writing plans. This knowledge of sources is based on the literature search and in the online environment today, the search is done via the internet. The stored memory is then used to allow the writer to proceed to the next stage and that is the "monitor" stage. This stage involves the writer going through planning, translating and revising/reviewing (or better known as the evaluation stage). Only after the writer is done in the "monitor" stage, then he/she can proceed to the task environment stage.

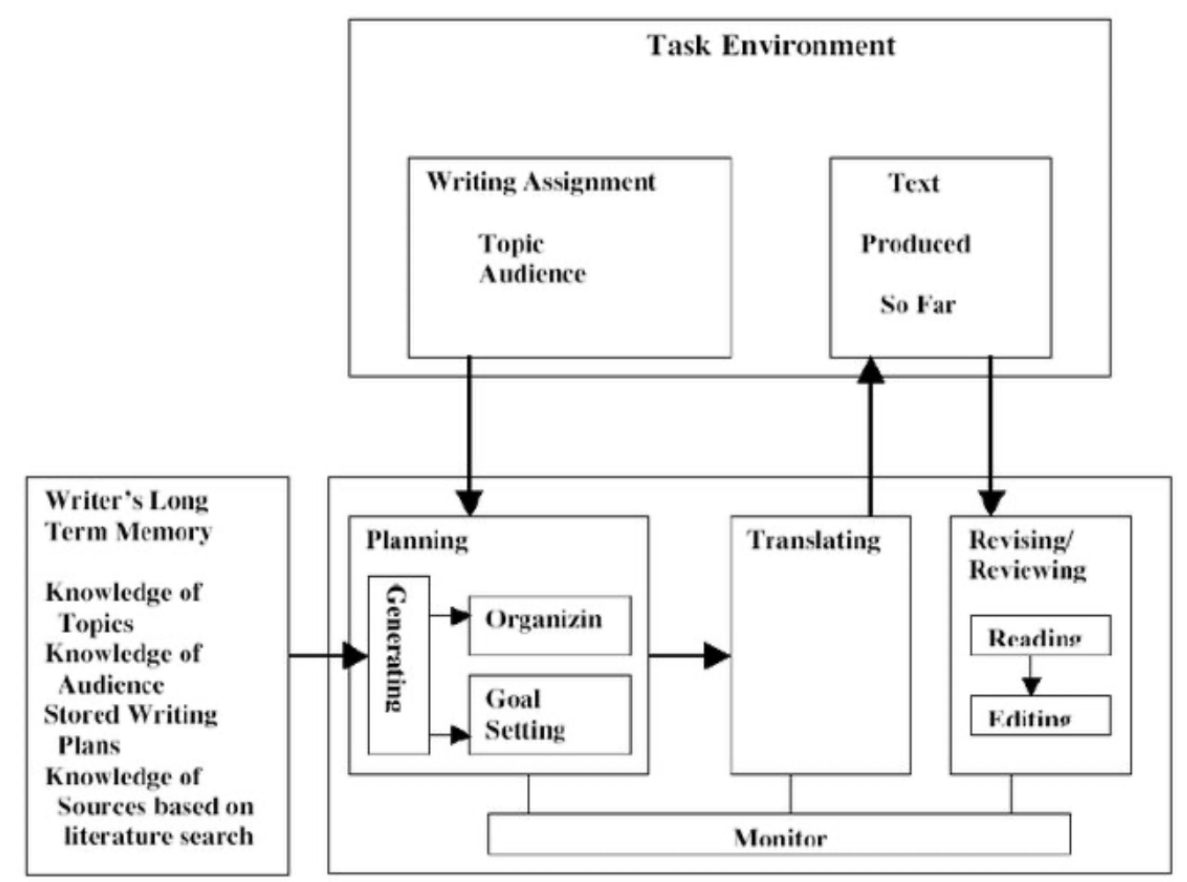

Figure 2- The Writing Process (source: Flower and Hayes, 1981)

\section{Past Studies}

The study by Loan (2022) investigated the challenges that EFL learners faced when they learned writing in an online course via Microsoft Teams. 96 respondents responded to a 10item questionnaire after attending a 10 week writing course. The findings revealed that learners faced nine kinds of challenges related to technical problems, lack of concentration, lack of interaction, time management, health problems, gaining knowledge, motivation, psychological problems, and collaboration.

Next another study was done by (Wahyuningsih, 2018). This qualitative study used observation, interview and documentation are conducted to gather data. The result indicates that some challenges faced by some learners in the academic writing includes the difficulties of how to start writing, lack of both intensive and extensive reading, limited exposures to English vocabularies, and lack of interest in writing English. In addition to that, the opportunities that could be exposed to enhance the process of teaching academic writing skills among learners. 


\subsection{Conceptual Framework of the Study}

This study is rooted form Garrison, Anderson \& Archer's (2001) cognitive presence and Flower and Hayes's(1981) process of writing to reveal the process of the learning of academic writing online. Cognitive presence is described as the extent of learners (writers) to construct meaning. This is done by sustaining the online communication. In the attempt to construct meaning, they connect and apply ideas,. They also use their critical thinking skills to evaluate their own writing. Similarly, in the writing process (figure 3 ), writers go through the cognitive presence by (a) planning, (b) translating and (c) evaluating their written product.

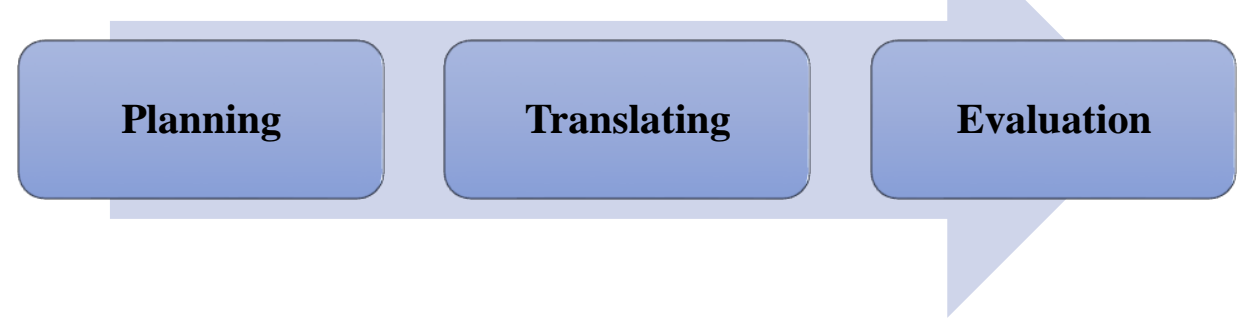

Figure 3- Conceptual Framework of the StudyLearning Academic Writing Online.

\section{Methodology}

This quantitative research is done to investigate how learners use cognitive and meta cognitive strategies when they learn French as a foreign language. The instrument used is a survey designed from Flower and Hayes (1981). 63 respondents were purposively chosen to answer the survey. The survey has 3 main sections. With reference to Table 1 , section $A$ has items on the demographic profile. Section B has 8 items on planning, section $C$ has 8 items translating and section $D$ has 7 items on evaluation.

\begin{tabular}{|c|c|c|}
\hline SECTION & STAGE & No of Items \\
\hline B & Planning & 8 \\
\hline C & Translating & 8 \\
\hline D & Evaluation & 7 \\
\hline \multicolumn{2}{|r|}{ Total number of Items } & 23 \\
\hline
\end{tabular}

Table 2 presents the reliability statistics for the instrument. SPSS analysis revealed a Cronbach alpha of .798 thus showing a good internal reliability of the instrument used. Data is collected online via goggle form. Data is then analysed using SPSS version 26. Analysed data is presented in the form of percentages and mean scores to answer the 2 research questions

Table 2- Reliability Statistics

\section{Reliability Statistics}

\begin{tabular}{r|r}
$\begin{array}{c}\text { Cronbach's } \\
\text { Alpha }\end{array}$ & N of Items \\
\hline .798 & 23 \\
\hline
\end{tabular}




\section{Findings}

Findings for Demographic Profile (63 respondents)

SECTION A- DEMOGRAPHIC PROFILE (PERSONAL INFORMATION)

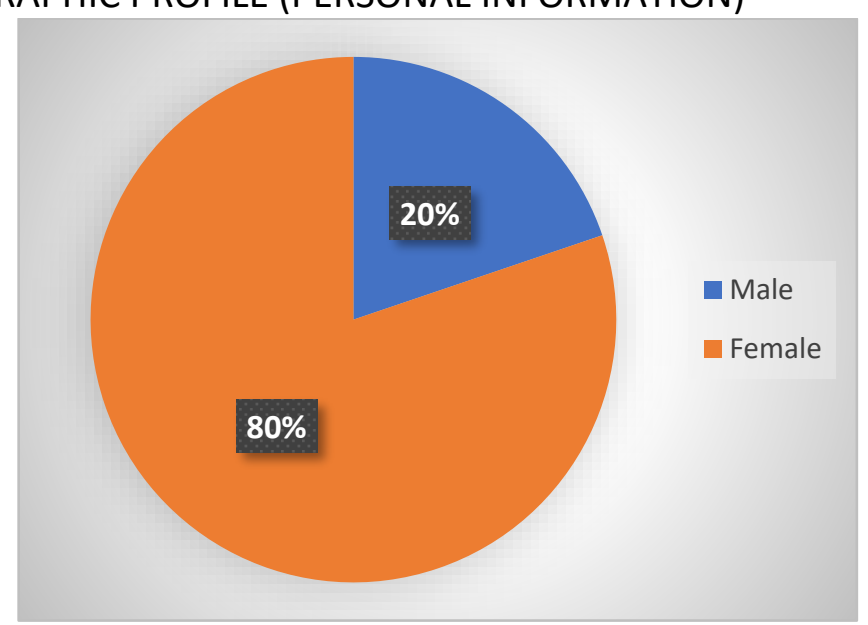

Figure 4- Percentage for Gender

Figure 4 shows the percentage for gender. Data revealed that the respondents were made up of $80 \%$ male and $20 \%$ female.

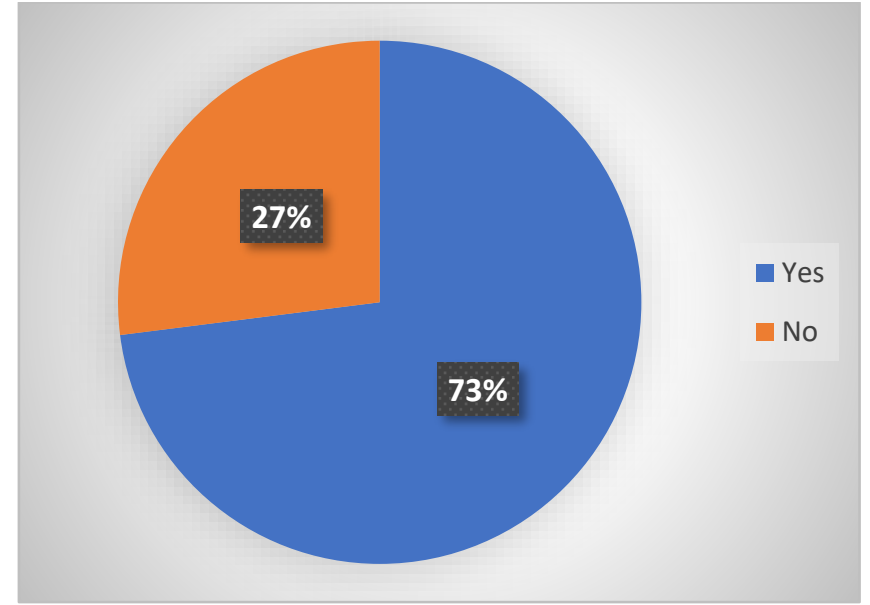

Figure 5-Percentage for Academic Writing History

Figure 5 presents the percentage for academic writing history. $73 \%$ were taught about how to cite in academic essays while $27 \%$ claimed they were not taught about citation skills prior to the online course.

\section{Findings for Planning}

This section presents data to answer research question 1-How do learners select content during online writing? The selection of content is done by looking for materials to be used in the write-up and this stage is known as the planning stage. 8 items were presented to reveal what writers do doing the planning stage. 
INTERNATIONAL JOURNAL OF ACADEMIC RESEARCH IN BUSINESS AND SOCIAL SCIENCES Vol. 12, No. 1, 2022, E-ISSN: 2222-6990 @ 2022 HRMARS

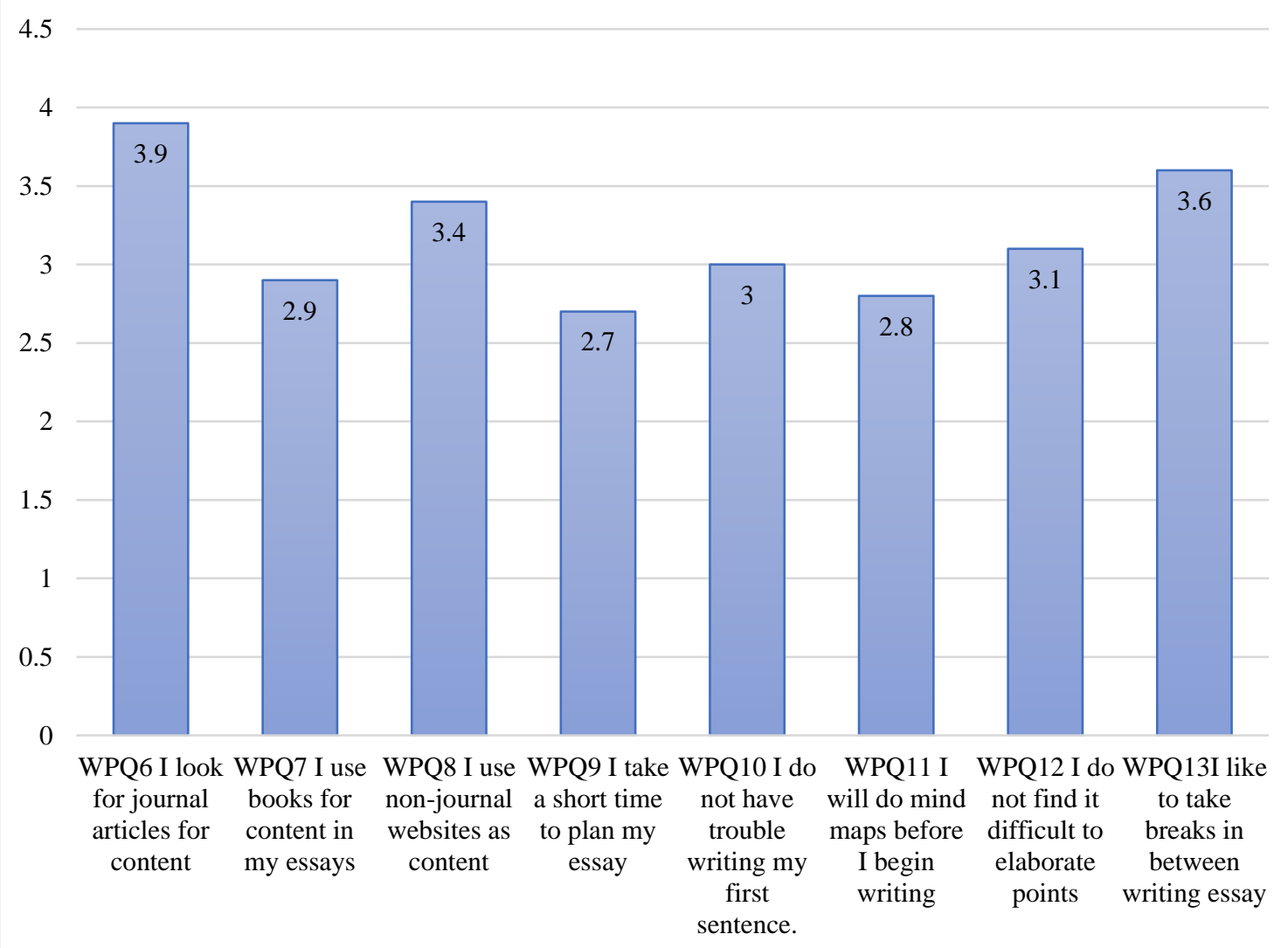

Figure 6- Mean for Planning

Figure 6 above presents the mean score for planning. The highest mean (3.9) is recorded for "look for journal articles for content". Next is "take breaks in between writing essay" (3.6). This is followed by "use non-journal websites as content" (3.4).

\section{Findings for Translating}

This section presents data to answer research question 2-How do learners connect ideas in online writing? The act of translating the information to be used in the content of the writeup includes the skills to connect ideas. 8 items reveal how writers translate their ideas. 
WT Q21I like to stop writing to get more ideas

WT Q20 I like to rehearse/try out ideas as drafts before I write my essay

WT Q19I like to rehearsed/tried out ideas verbally before I write my essay WT Q18 I usually check my grammar while I write my
essay

WT Q17 I like to elaborate using examples that I know

WT Q 16 I like to elaborate using information from the articles

WT Q15 I only read the sections I need in the articles and begin writing

WT Q14 I try to understand the whole article before I begin taking writing

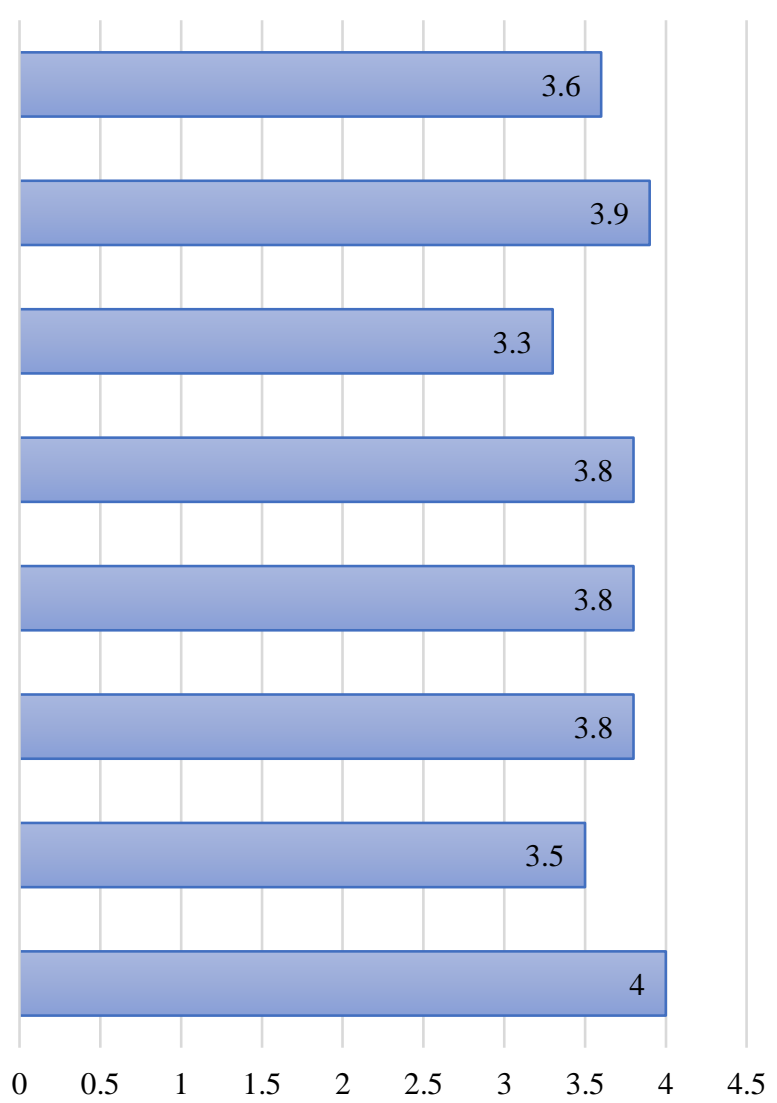

Figure 7 -Mean for Translating

The findings for translating is presented in figure 7. The highest mean (4) is recorded for "try to understand the whole article before begin taking the writing course". This is followed by "rehearse ideas as drafts " (3.9). Next, respondents (mean= 3.8) also reported that they "tried to elaborate using information from the articles", "liked to elaborate using examples that they knew" and also "checked grammar while writing".

\section{Findings for Evaluation}

This section answers research question 3-How do learners support discourse in online writing? When the writers are reviewing their work, they would try their level bets to support the discourse that they have thus chosen. 7 items show how writers review their work. 


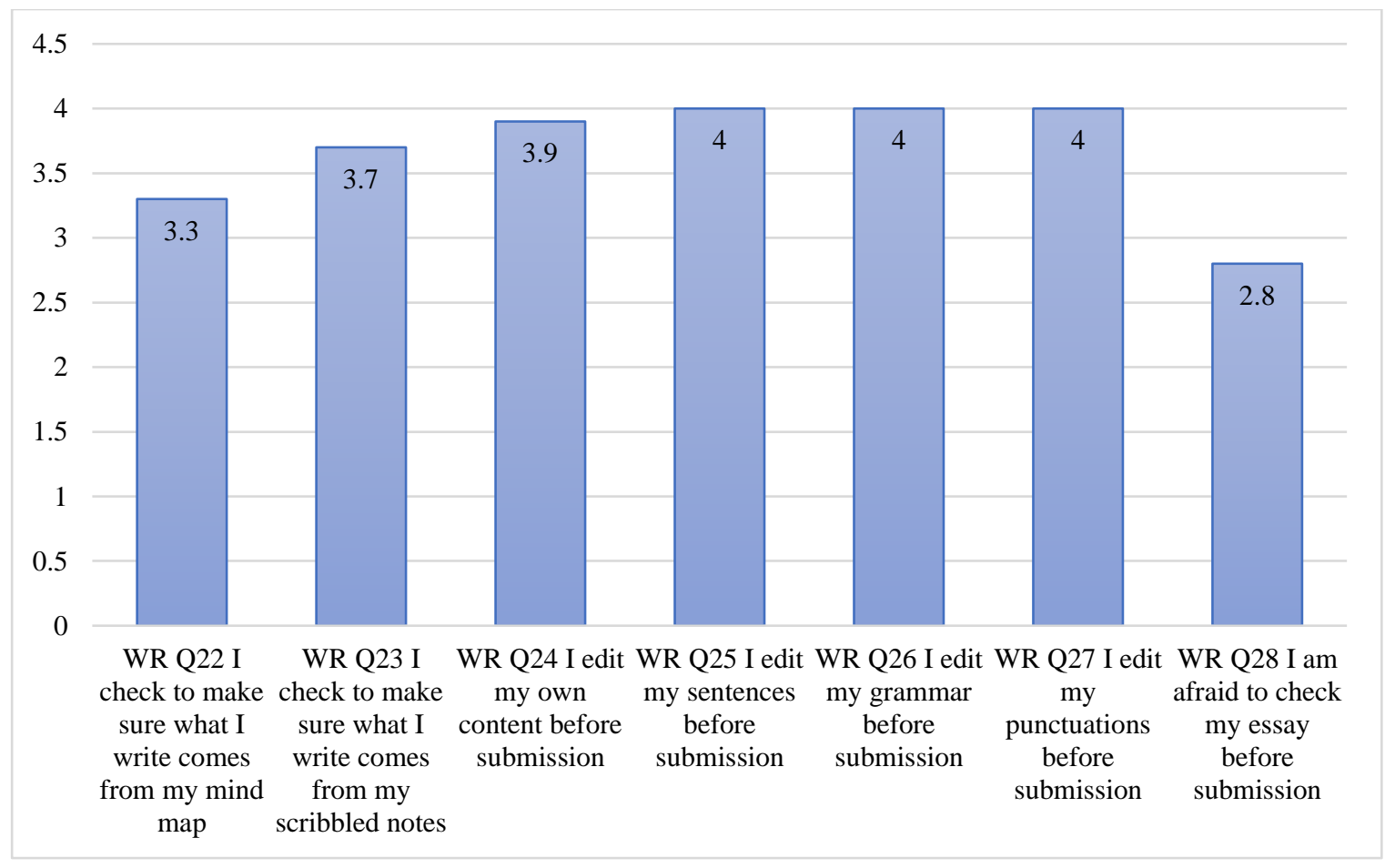

Figure 8- Mean for Reviewing

Figure 8 presents the mean for evaluation. The highest mean of 4 are for items "edit sentences before submission", "edit grammar before submission", and "edit punctuations before submission". Next, respondents (3.9) also reported that they "edited content before submission".

\section{Conclusion}

Summary of Findings and Discussion

The summary of findings for all the three research questions are presented in table 3. The lowest mean (3.2) is for planning. The highest mean (both at 3.7) is for translating and reviewing. Writers perceive that they needed less time planning and searching for materials compared to for the actual write-up (translating) and reviewing.

Table 3- Total mean for academic writing process online

\begin{tabular}{|l|l|}
\hline TOTAL MEAN FOR PLANNING & 3.2 \\
\hline TOTAL MEAN FOR TRANSLATING & 3.7 \\
\hline TOTAL MEAN FOR REVIEWING & 3.7 \\
\hline
\end{tabular}

This finding is not in accordance with the study by Rahmat, Aripin, Lin, Whanchit, and Khairuddin (2020) who found that planning had the highest mean compared to translating and reviewing. What is interesting is that the study looked at academic writing done in the traditional face-to-face setting and the current study looked at learning academic writing via online. The study by Wahyuningsih (2018) reports that among the difficulties of the academic writer is the initial stage. Perhaps this study can be said to be in accordance to the study by Wahyuningsih (2018) because giving a low mean for the planning stage could indicate the stage to be difficult and the writers would rather brush past to the stages that involves the write-up. 
Pedagogical Implications and Suggestions for Future Research

The study by Loan (2022) reported that among some of the challenges of online writing are technical problems, lack of concentration, lack of interaction, time management, and collaboration. This study showed that learners undergo the planning, translating and reviewing stage on their own on their computer. Perhaps the learning of academic writing online could be done as part of group work activities to sustain motivation and to increase interaction among learners. Writing itself is a long, lonely and confusing process at times. Having peers working together in group activities to lead to write-ups may help improve time management and even improve concentration among writers. It is thus suggested that future research explore what learners feel about learning academic writing (a) online and (b) as group work. Perhaps the collection of data could include the interviewing of what writers feel about learning online academic writing alone and as a group.

\section{References}

Carolan, F., \& Kyppö, A. (2015). Teaching process writing in an online environment. In J. Jalkanen, E. Jokinen, \& P. Taalas (Eds), Voices of pedagogical development - Expanding, enhancing and exploring higher education language learning (pp. 13-30). Dublin: Research-publishing.net. doi:10.14705/rpnet.2015.000285

Flower, L., \& Hayes, J. (1981). A Cognitive Process Theory of Writing. College Composition and Communication, Vol 31(21), pp 21-32. Retrieved from https://www.jstor.org/stable/356600

Garrison, D. R., \& Arbaugh, J. B. (2007). Researching the community of inquiry framework: Review, issues, and future directions/ Internet and Higher Education 10, pp. 157-172. Retrieved from http://reinventnet.org/moodle/pluginfile.php/1196/mod_resource/content/3/COIrevi ew.pdf

Garrison, D. R., Anderson, T., \& Archer, W. (2001). Critical Thinking, Cognitive Presence, and Computer Conferencing in Distance Education. American Journal of Distance Education. Retrieved from https://doi.org/10.1080/08923640109527071

Haron, H., \& Rahmat, N. H. (2020) Exploring the Theory of Acitivity in English language Writing: The Case for Whatsapp. International Journal of Asian Social Science, Vol 10911) pp 671-684. Retrieved from http://doi.dx.org/ 10.18488/journal.1.2020.1011.671.684

Hidayati, K. H. (2018) Teaching Writing to EFL Learners: An Investigation of Challenges Confornted by Indonesian Teachers. LANGKAWI- Journal of the Association for Arabic and English, Vo 491), pp 21-31. Retrieved from https://ejournal.iainkendari.ac.id/langkawi/article/view/772

Loan, B. T. K. (2022) The Challenges of Online Writing Learning via Microsoft teams. AsiaCALL Online Journal, Vol 1391), pp 132-149 Retrieved from https://asiacall.info/acoj/index.php/journal/article/view/115

Moore, M. G. (1989). Three types of interaction. The American Journal of Distance Education, 3(2), 1-6. https://doi.org/10.1080/08923648909526659

Othman, S., Rahmat, N. H., Aripin, N., \& Sardi, J. (2022) Writers' Beliefs in Academic Writing. International Journal of Academic Writing in Business and Social Sciences, Vol 12(1), pp 1340-1350. Retrieved from hppt://dx.doi.org/IJARBSS/v12-i1/11312

Rahmat, N. H. (2020) Thinking about Thinking in Writing. European Journal of Literature, Language and Linguistic Study, Vol 3(4), pp 20-36. Retrieved from https://oapub.org/lit/index.php/EJLLL/article/view/153 
Rahmat, N. H., Aripin, N., Lin, N. M., Whanchit, W., and Khairuddin, Z. (2020) Exploring the Connections between Critical thinking Skills and Academic Writing. International Journal of Asian Social Science, Vol 10(2), pp 118-128. Retrieved from http://dx.doi.org/10.18488/journal.1.2020.102.118.128

Siemens, G. (2005). Connectivism: A learning theory for the digital age, International Journal of Instructional Technology and Distance Learning, 2(1). Retrieved from http://www.itdl.org/Journal/Jan_05/article01.htm

Wahyuninhshi,S. (2018) Challenges and Opportunities of Teaching Academic Writing Skills: A Case Study of Students at IAIN Kudus. Jurnal Edulingu, Vol 5(1), pp 15-24. Retrieved from https://ejournal.unisnu.ac.id/JE/article/viewFile/820/1072 